\title{
LONGEVITY OF CALIFORNIAN THISTLE ROOTS
}

\author{
G.W. BOURDÔT ${ }^{1}$, D.M. LEATHWICK ${ }^{2}$ and G.A. HURRELL ${ }^{1}$ \\ ${ }^{1}$ AgResearch, P.O. Box 60, Lincoln \\ ${ }^{2}$ AgResearch, Private Bag 11008, Palmerston North
}

\begin{abstract}
In two experiments, sheep pastures supporting manipulated ranges of root biomass of Californian thistle (Cirsium arvense (L.) Scop.) in autumn 1996 and 1997 were mown weekly over the subsequent growing seasons of 1997 and 1998 respectively. This treatment minimised whole season photosynthetic opportunity in the Californian thistle and the formation of new root biomass, allowing the survival of existing root biomass to be measured. Autumnal root biomass in May 1997 was $6 \%$ of that in May 1996, and in May 1998 it was $10 \%$ of that in May 1997. These results support the hypothesis that a high percentage of the over-wintering storage root biomass of Californian thistle does not survive beyond the end of the next growing season.
\end{abstract}

Keywords: Cirsium arvense, mowing, defoliation, adventitious root buds, adventitious shoots.

\section{INTRODUCTION}

Californian thistle exhibits a perennial geophyte life-form (Grime et al. 1988). The aerial shoots senesce completely in the late autumn and the plant persists over the winter months as a thickened root system supporting numerous adventitious buds (Moore 1975). During the winter months these buds draw upon stored carbohydrate reserves to form vertically growing shoots that emerge above the soil in spring, after frosts have ceased, to re-establish a population of assimilating aerial shoots (G. Bourdôt, unpubl. data). The storage roots together with their populations of buds are a key stage in the life-history of Californian thistle. Effective management of this weed relies upon a thorough understanding of the behaviour of these roots. They have been the focus of many studies describing their morphology, formation, lateral extension rate, depth penetration in soil and response to fragmentation (Moore 1975). However their longevity has received little attention. Donald (1994) in a review of the biology of Californian thistle stated that "There are no estimates of root system persistence for established patches of Canada thistle". Not until we have some understanding of root longevity in undisturbed populations, will we be able to develop a realistic population model of Californian thistle that might allow us to predict the outcome of, and select between, alternative control measures (Donald 1990).

Experiments near Palmerston North (Hartley et al. 1984) and in Southland (Mitchell and Abernethy 1993) have demonstrated that repeated defoliation of Californian thistle over a $2-3$ year period substantially reduces the density of the shoot population, suggesting that the storage roots have limited persistence. Rogers (1928) suggested that they live only about two years, and based on field excavations, Wales et al. (1964) hypothesised that they persist for little more than twelve months, disappearing after producing a flush of shoots. In Canterbury, New Zealand, decayed roots occur in pasture populations of the thistle throughout the year (G. Bourdôt, unpubl. data), implying that root death is a continuous process. Bourdôt et al. (1998) found that the autumnal root biomass of the thistle in pasture was a linear function of aerial shoot biomass duration during the preceding growing season. The zero intercept term in this function implied that the roots giving rise to the shoot population in the current growing season had all disappeared by the autumn and that the root biomass present in the autumn consists entirely of newly formed roots. As a result, Bourdôt 
et al. (1998) hypothesised that the storage roots in Californian thistle in Canterbury pastures do not survive beyond the end of the growing season following that in which they are produced, i.e. they persist no longer than twelve months. To confirm this hypothesis more directly, each of the two experiments described in Bourdôt et al. (1998) was continued for a further 12 months. All plots were mown weekly to minimise assimilatory opportunity and root biomass was measured at the end of the 12 month period. This paper reports on the results of this further investigation.

\section{MATERIALS AND METHODS}

Experiments 1 and 2 in Bourdôt et al. (1998) each had two replicates of eight mowing treatments (a $2 \times 2 \times 2$ factorial combination of mown and not mown either early (Nov), mid (Jan) and late (Feb/Mar) in the growing season). The resulting plots contained Californian thistle root populations ranging in biomass from 24 to $66 \mathrm{~g} / \mathrm{m}^{2}$ in autumn 1996 (Exp. 1) and from 28 to $155 \mathrm{~g} / \mathrm{m}^{2}$ in autumn 1997 (Exp. 2). This offered a unique opportunity to measure the survival of root populations of varying initial size. In the following growing seasons, from 23 September 1996 until 14 April 1997 in Exp. 1, and from 14 October 1997 until 10 April 1998 in Exp. 2, each plot was mown weekly to a height of $15 \mathrm{~mm}$ (or less) above ground level. A John Deere Ride-on rotocut mower was used. On 12 and 14 May 1997 in Exp. 1, and 2 to 4 June 1998 in Exp. 2, ten 155 $\mathrm{mm}$ diameter x $350 \mathrm{~mm}$ deep soil cores were taken from each of the $60 \mathrm{~m}^{2}$ plots. Plot areas sampled in the preceding year (Bourdôt et al. 1998) were avoided. The ten cores were bulked and the Californian thistle roots were extracted, dried and weighed, providing two replicate samples of 1997 and 1998 autumnal root biomass for each of the eight 1996 and 1997 autumnal root populations respectively.

For each of the two experiments, the mean autumnal root biomass for each of the eight populations following weekly defoliation throughout the growing season was expressed as a percentage of the mean root biomass measured 12 months previously.

\section{RESULTS AND DISCUSSION}

Autumnal root mass in each of the eight Californian thistle populations generated by the previous mowing regimes in Exp. 1 and 2, was in all cases substantially lower in the autumn following weekly mowing than it was in the preceding autumn (Table 1). The root biomass at the end of the season of weekly defoliation was on average just $6 \%$ ( $\pm 4 \%$ [95\% confidence interval], Exp. 1$)$ and $10 \%$ ( $\pm 4 \%$, Exp. 2$)$ of the biomass present in the preceding autumn.

The aim of this study was to test the hypothesis that little if any of the storage root biomass in intact Californian thistle populations in pastures grazed by sheep in Canterbury survives beyond the end of the growing season following that in which it was produced. Our approach to this has been to minimise new root biomass production in the thistle for an entire growing season by frequent mowing to minimise the wholeseason assimilatory opportunity. The root biomass measured at the end of the growing season may then be considered to be entirely that formed in the preceding year since new root biomass cannot form in the absence of assimilation. This does not of course discount the possibility that new roots (as distinct from new root biomass) may be formed by redistribution of old root biomass, but since our interest is primarily in the persistence of root biomass from one year to the next, this need not concern us here.

The weekly mowing treatment in both experiments 1 and 2 prevented the Californian thistle shoots from forming elongated stems, forcing them to remain as very small vegetative rosettes with their growing points below the cutting height of the mower. Since root biomass production is a linear function of aerial shoot biomass duration in Californian thistle (Bourdôt et al. 1998), we may assume that very little new root tissue was formed under the weekly mowing regime imposed in this study.

But before we may interpret the large fall in autumnal root biomass under our weekly mowing treatment as adequately simulating natural attrition of root biomass in an undisturbed thistle population, we must discount the possibility that the frequent mowing caused root biomass loss. One possible argument is that the survival of "old" storage roots is dependent upon assimilates from current photosynthesis. This is 
TABLE 1: Autumnal root biomass $\left(\mathrm{g} / \mathrm{m}^{2}\right)$ in Californian thistle before and after weekly mowing of aerial shoot populations. "Initial", "Final" and "\%" refer respectively to the initial mass of the root system in the autumn preceding the weekly mowing, the root biomass in the autumn after the weekly mowing and Final expressed as a percentage of Initial.

\begin{tabular}{|c|c|c|c|c|c|c|}
\hline \multirow{2}{*}{$\begin{array}{l}\text { Previous mowing } \\
\text { treatment }^{1}\end{array}$} & \multicolumn{3}{|c|}{ Experiment 1} & \multicolumn{3}{|c|}{ Experiment 2} \\
\hline & Initial $^{2}$ & Final & $\%$ & Initial $^{2}$ & Final & $\%$ \\
\hline None & 66 & 3.4 & 5 & 155 & 13 & 8 \\
\hline Early & 38 & 5.0 & 13 & 95 & 10 & 10 \\
\hline Mid & 61 & 1.1 & 2 & 90 & 8 & 9 \\
\hline Late & 34 & 0.5 & 1 & 78 & 7 & 8 \\
\hline Early \& Mid & 56 & 5.2 & 9 & 103 & 10 & 10 \\
\hline Early \& Late & 28 & 0.1 & 0 & 57 & 4 & 7 \\
\hline Mid \& Late & 29 & 2.1 & 7 & 39 & 8 & 21 \\
\hline Early, Mid \& Late & 24 & 1.3 & 5 & 28 & 2 & 7 \\
\hline $\begin{array}{l}\text { Mean } \\
\text { (and 95\% Confiden }\end{array}$ & interval $^{3}$ & & $6( \pm 4)$ & & & $10( \pm 4)$ \\
\hline
\end{tabular}

${ }^{1}$ Time in previous growing season when the mowing that generated the "Initial" root masses was conducted.

2 These are arithmetic means, so differ from their geometric counterparts given in Table 1, Bourdôt et al. (1998).

${ }^{3}$ Each $95 \%$ confidence interval was calculated from the corresponding percentages presented in the Table.

improbable given that these structures are perennating organs, having evolved to enable the species to over-winter without photo-assimilate input. A second possible argument is that the weekly mowing treatment caused the "old" roots to mobilise more carbohydrate food reserves than would have occurred in an intact population of the thistle, resulting in our data overestimating the rate of root biomass loss. Root biomass loss in Californian thistle is known to result when dormant root buds are stimulated to form shoots after root fragmentation (Nadeau and Vanden Born 1989; McAllister and Haderlie 1985). Decapitation of the aerial shoot in young plants growing from seed has also been shown to have this effect (Wilson 1979), and there is anecdotal evidence that this occurs in well established field populations. However it is unknown whether repeated partial defoliation, in the absence of decapitation, results in the mobilisation of reserves in "old" roots, either by stimulation of root bud growth or by some other process. So it is with some uncertainty that we assume here that the weekly mowing imposed in our experiment had no effect on the survival of "old" roots.

We cannot, from this experiment, determine whether the small quantity of root biomass present in both experiments in the autumn after weekly mowing was new root formed by the regularly defoliated shoots or residual roots from the previous year. If the former were the case our data overestimates root biomass longevity. Secondly, if we are wrong in assuming that our regular defoliation did not stimulate reserve usage in the old roots, then we will have underestimated the natural longevity of the storage root biomass. If our assumption is correct, our results support the hypothesis that the storage root biomass of an intact Californian thistle population in a Canterbury pasture does not persist beyond the summer growing season following that in which it was formed. This is a least a good working hypothesis to include in a population model for Californian thistle in pasture.

\section{ACKNOWLEDGEMENTS}

We thank Dave Saville, AgResearch, Lincoln, for help with the statistical design of the experiments and comments on the manuscript. We also thank the Foundation for Research, Science and Technology for funding this project and Christine Galbraith, AgResearch, Lincoln, for technical support. 


\section{REFERENCES}

Bourdôt, G.W., Leathwick, D.M., Hurrell, G.A. and Saville, D.J., 1998. Relationship between aerial shoot and root biomass in californian thistle. Proc. 51 st N.Z. Plant Prot. Conf.: 28-32.

Donald, W.W., 1990. Management and control of Canada thistle (Cirsium arvense). Rev. Weed Sci. 5: 193-250.

Donald, W.W., 1994. The biology of Canada thistle (Cirsium arvense). Rev. Weed Sci. 6: 77-101.

Grime, J.P., Hodgson, J.G. and Hunt, R., 1988. Cirsium arvense (L.) Scop. Pp 196-197 In: Comparative plant ecology - a functional approach to common British species, J.P. Grime, J.G. Hodgson and R. Hunt (Eds); Unwin Hyman, London.

Hartley, M.J., Lyttle, L.A., and Popay, A.I., 1984. Control of Californian thistle by grazing management. Proc. 37th N.Z. Plant Prot. Conf.: 24-27.

McAllister, R.S. and Haderlie, L.C., 1985. Seasonal variations in Canada thistle (Cirsium arvense) root bud growth and root carbohydrate reserves. Weed Sci. 33: 44-49.

Mitchell, R.B. and Abernethy R.J., 1993. Integrated management of Californian thistle in pasture. Proc. 46th N.Z. Plant Prot. Conf.: 278-281.

Moore, R.J., 1975. The biology of Canadian weeds. 13. Cirsium arvense (L.) Scop. Can. J. Plant Sci. 55: 1033-1049.

Nadeau, L.B. and Vanden Born, W.H., 1989. The root system of Canada thistle. Can. J. Plant Sci. 69: 1199-1206.

Rogers, C.F., 1928. Canada thistle and Russian Knapweed and their control. Col. Agric. Exp. Stat. Bull. 434: 44.

Wilson, R.G. Jr., 1979. Germination and seedling development of Canada thistle (Cirsium arvense). Weed Sci. 27:146-151. 